\section{Discoversys \\ Published by DiscoverSys \\ Time of colostrum discharge of more than six hours as a risk factor for physiological jaundice in neonates}

\author{
Ni Kadek Muliawati, ${ }^{1 *}$ I Gusti Ayu Trisna Windiani, ${ }^{2}$ Anak Agung Sagung Sawitri, ${ }^{3}$ \\ Luh Seri Ani ${ }^{3}$
}

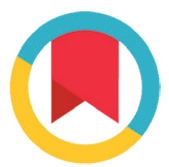

CrossMark

\title{
ABSTRACT
}

Background and purpose: Neonatal jaundice is both a physiological and pathological condition. Neonatal physiological jaundice occurs within 3-5 days after the baby is born. Publications about time of colostrum discharge and neonatal jaundice are still limited. This study aims to determine the risk time of colostrum discharge more than 6 hours to physiological jaundice in neonates.

Methods: A case control study was conducted at the Sanglah General Hospital in Denpasar from August to December 2017. The number of cases was 55 neonates with physiological jaundice and the number of controls was 55 neonates without physiological jaundice. Cases and controls were selected by consecutive sampling. The occurrence of physiological jaundice was obtained by direct observation and the degree of jaundice was determined based on the division of Kramer's body zone. Neonates with the Kramer grades I and II at the age of 3-5 days were classified as experiencing physiological jaundice (as cases) and neonates with a Kramer grade of 0 at the age of 3-5 days were classified as not jaundice (as controls). Cases were matched with controls by sex and age of the neonates. Data on maternal socio-demographic characteristics, time of colostrum discharge, early breastfeeding initiation and 24-hour breastfeeding frequency were obtained by interview; data on jaundice was obtained by observation while mode of delivery, parity, history of pre-eclampsia, prematurity, neonatal birth weight, history of birth trauma (cephalic hematoma), history of asphyxia and major congenital abnormalities were obtained from medical records. Multivariate analysis with binary logistic regression was carried out to determine the adjusted odds ratio (AOR) time of colostrum discharge .

Results: The characteristics of cases and controls were found to be similar in terms of maternal education, neonatal age and sex, parity and pre-eclampsia history. Significant time of colostrum discharge $>6$ hours was found to be associated with physiological jaundice with $A 0 R=2.57$ ( $95 \% \mathrm{Cl}: 1.04-6.37)$. In this study, variables that were not found to be the risk factors of physiological jaundice in neonates were: cesarean delivery $(\mathrm{AOR}=0.36 ; 95 \% \mathrm{Cl}$ : 0.09-1.41; $\mathrm{p}=0.14)$, breastfeeding frequency within 24 hours (AOR $=2.20 ; 95 \% \mathrm{Cl}: 0.47-$ $10.23 ; p=0.31)$ and early breastfeeding initiation $(A O R=0.71 ; 95 \% \mathrm{Cl}$ : $0.19-2.59 ; p=0.60$ )

Conclusion: time of colostrum discharge $>6$ hours is a risk factor for neonatal jaundice. Efforts should be made to accelerate the release of colostrum in order to prevent neonatal jaundice.
${ }^{1}$ Wira Medika Bali Health Insitute, ${ }^{2}$ Department of Pediatrics, Faculty of Medicine, Udayana University, ${ }^{3}$ Department of Public Health and Preventive Medicine, Faculty of Medicine, Udayana University
${ }^{*}$ Correspondence to: Ni Kadek Muliawati, Wira Medika Bali Health Insitute muliawati.wika@gmail.com

Keywords: Colostrum, physiological jaundice, neonates, Bali

Cite This Article: Muliawati, N.K., Windiani, I.G.A.T., Sawitri, A.A.S., Ani, L.S. 2019. Time of colostrum discharge of more than six hours as a risk factor for physiological jaundice in neonates. Public Health and Preventive Medicine Archive 7(1): 44-48. D0I:10.15562/phpma.v7i1.193

\section{INTRODUCTION}

Neonatal jaundice is often found in infants especially in Southeast Asia. ${ }^{1}$ The proportion of physiological and pathological neonatal jaundice is reported to be $55.2 \%$. $^{2}$ Pathological neonatal jaundice which is characterized by hyperbilirubinemia $>12.9 \mathrm{mg} / \mathrm{dl}$ was reported in $4.8 \%$ of newborns in the first week of birth. ${ }^{3}$ Another study reported the incidence of jaundice among preterm neonates at $57.50 \%$ and term neonates at $37.5 \% .^{4} \mathrm{~A}$ study in Indonesia found a neonatal jaundice incidence of $32.1 \%$, in which $42.97 \%$ among neonates with low birth weight and $29.7 \%$ among term neonates. ${ }^{5}$

Most physiological neonatal jaundice cases do not require treatment, but such infants need to be monitored to prevent possible complications of bilirubin encephalopathy. ${ }^{6}$ The National Institute for Health and Clinical Excellence (NICE) Clinical Guidelines recommends a neonatal jaundice management which includes information about neonatal jaundice for parents and caregivers, detection among all newborns and identification of neonatal jaundice risk factors. ${ }^{7}$ As one of the neonatal jaundice risk factors is breastfeeding. Normally, the time of colostrum discharge is within three days after the labor if the baby is breastfed. ${ }^{8}$ NICE also recommends the focus of studies to evaluate the underlining factors associated between breastfeeding and jaundice.

Various studies have been conducted to evaluate the association between breastfeeding and other risk factors with the incidence of neonatal jaundice. Some of the risk factors that have been reported are the mode of delivery, ${ }^{9-12}$ early breastfeeding initiation ${ }^{13-16}$ and frequency of breastfeeding in 24 hours. ${ }^{17,18}$ Other studies found that factors related to hyperbilirubinemia were gestational age and exclusive breastfeeding. ${ }^{19}$ We found only one published study related to the time difference of 
colostrum administration towards the incidence of neonatal jaundice. A study conducted in Indonesia which used a cohort method found an association between differences in the timing of colostrum discharge to the incidence of neonatal jaundice in newborns. ${ }^{20}$ Our study was conducted to determine the risk time of colostrum discharge to neonatal jaundice.

\section{METHODS}

A case control study was conducted at the Cempaka Maternity Room 2, Sanglah General Hospital in Denpasar. Cases and controls were obtained from the registry in the delivery room from August to December 2017. This room has 16 beds and is a nursing room joining the mother and postnatal care space. On average one baby was born in this room daily, with an average stay for two to three days.

The number of cases was 55 neonates with physiological jaundice from 65 neonates and the number of controls was 55 neonates without physiological jaundice from 74 neonates in the same period. The sample size was calculated by $95 \%$ confidence level, $80 \%$ power, anticipated odd ratio of 3.0 , proportion time of colostrum discharge more than six hours in infants who did not experience neonatal jaundice is $20 \%{ }^{21}$ Cases and controls were matched by sex and age. Cases and controls were selected by consecutive sampling. The incidence of jaundice was obtained by observation while baby was hospitalized on the first and second day, and with a home visit on the third until the fifth day. The degree of jaundice was determined based on the division of

Table 1 Characteristics of cases and controls

\begin{tabular}{|c|c|c|c|}
\hline & Cases & Controls & \\
\hline Characteristics & $n=55$ & $n=55$ & $\mathbf{p}$ \\
\hline $\begin{array}{l}\text { Mother's education (years), } \\
\text { mean } \pm \text { SD }\end{array}$ & $10.85 \pm 2.48$ & $10.53 \pm 2.82$ & $0.68^{*}$ \\
\hline Neonate age (days), mean \pm SD & $4.15 \pm 0.62$ & $4.29 \pm 0.66$ & $0.21^{\star}$ \\
\hline \multicolumn{4}{|l|}{ Sex of neonates } \\
\hline Male & $38(69.09)$ & $38(69.09)$ & $1.00^{* *}$ \\
\hline Female & $17(30.91)$ & $17(30.91)$ & \\
\hline \multicolumn{4}{|l|}{ Parity } \\
\hline $1-3$ & 49 (89.09) & $48(87.27)$ & $0.77^{\star \star}$ \\
\hline $4-6$ & $6(10.91)$ & $7(12.73)$ & \\
\hline \multicolumn{4}{|l|}{ Preeclampsia } \\
\hline Yes & $6(10.91)$ & $5(9.09)$ & $0.75^{\star *}$ \\
\hline No & 49 (89.09) & $50(90.91)$ & \\
\hline
\end{tabular}

*Analysed with Mann Whitney U Test

${ }^{* *}$ Analysed with Chi-Square Test
Kramer's body zone, where physiological jaundice is identified in the head and chest area. ${ }^{22}$ Cases were defined by a trained midwife as neonates with jaundice Kramer grades I and II at 3-5 days after delivery and controls were defined as neonates with Kramer grade 0 at the age of 3-5 days. All mothers who exclusively breastfed their baby and signed the informed consent were included in the study. The exclusion criteria were neonates with a gestational age of less than 37 weeks, birth weight less than 2500 grams, APGAR score $<6$, with vacuum labor and cephalic hematoma from a trauma.

Data was collected by conducting interviews, observation and extraction of medical records. Data collected by interviews were the demographic characteristics of the mother, time of colostrum discharge and other variables considered as confounding variables, namely the mode of delivery, early breastfeeding initiation and the frequency of breastfeeding within 24 hours. The questionnaire consisted of two parts, namely the characteristics of respondents and questions related to the time of colostrum discharge, early breastfeeding initiation and the frequency of breastfeeding within 24 hours. Explanation about the term of "colostrum" was provided during the interview. Time of colostrum discharge was defined as the time between the baby labor (both spontaneous or by cesarean section) and the first time of colostrum discharge. The time of colostrum discharge was classified into $\leq 6$ hours and $>6$ hours if the time of colostrum discharge was more than 6 hours. Early breastfeeding initiation was classified as "yes" if early breastfeeding initiation was provided and "no" if it was not provided; breastfeeding frequency in 24 hours was classified as $<8$ times if breastfeeding was provided less than eight times in 24 hours and $\geq 8$ times when provided more than or equal to eight times in 24 hours. Data collected by observation was the degree of jaundice and data collected through extraction of medical records included the method of delivery, parity, history of pre-eclampsia, prematurity birth, neonatal birth weight, history of birth trauma (cephalic hematoma), history of asphyxia and major congenital abnormalities. Multivariate analysis with binary logistic regression was carried out to determine the adjusted odds ratio (AOR) time of colostrum discharge. This study has been approved by the Ethics Committee of Faculty of Medicine Udayana University/Sanglah General Hospital on 12 July 2017.

\section{RESULTS}

Table 1 shows a comparison of cases and controls by mother's education, neonates' sex and age, parity and history of pre-eclampsia. There were no significant differences between cases and controls in 
Table 2 Crude OR of risk factors for physiologic jaundice in neonates

\begin{tabular}{|c|c|c|c|c|c|}
\hline & Cases & Controls & & & \\
\hline Variable & n (\%) & n (\%) & Crude OR & $95 \% \mathrm{Cl}$ & $\mathbf{p}$ \\
\hline \multicolumn{6}{|l|}{ Birthing methods } \\
\hline Caesarian & $14(25.45)$ & $27(49.09)$ & \multirow[t]{2}{*}{0.35} & \multirow[t]{2}{*}{$0.14-0.85$} & \multirow[t]{2}{*}{0.01} \\
\hline Spontaneous & $41(74.55)$ & $28(50.91)$ & & & \\
\hline \multicolumn{6}{|c|}{ Early breastfeeding initiation } \\
\hline No & $21(38.18)$ & $31(56.36)$ & \multirow[t]{2}{*}{0.48} & \multirow[t]{2}{*}{$0.21-1.09$} & \multirow[t]{2}{*}{0.06} \\
\hline Yes & $34(61.82)$ & $24(43.64)$ & & & \\
\hline \multicolumn{6}{|c|}{ Time of colostrum discharge } \\
\hline$>6$ hours & $25(45,45)$ & $20(36.36)$ & \multirow[t]{2}{*}{1.46} & \multirow[t]{2}{*}{$0.63-3.36$} & \multirow[t]{2}{*}{0.33} \\
\hline$\leq 6$ hours & $30(54.55)$ & $35(63.64)$ & & & \\
\hline \multicolumn{6}{|c|}{$\begin{array}{l}\text { Breastfeeding frequency in } 24 \\
\text { hours }\end{array}$} \\
\hline$<8$ times & $6(66.67)$ & $3(33.33)$ & \multirow[t]{2}{*}{2.12} & \multirow[t]{2}{*}{$0.42-13.74$} & \multirow[t]{2}{*}{0.29} \\
\hline$\geq 8$ times & $49(48.51)$ & $52(51.49)$ & & & \\
\hline
\end{tabular}

Table 3 Adjusted OR of risk factor for physiologic jaundice in neonates

\begin{tabular}{|c|c|c|c|}
\hline Variables & AOR & $95 \% \mathrm{Cl}$ & $\mathbf{p}$ \\
\hline Neonates age (days) & 0.59 & $0.31-1.15$ & 0.12 \\
\hline \multicolumn{4}{|l|}{ Birthing methods } \\
\hline Spontaneous & 1 (Ref) & & \\
\hline Caesarian & 0.36 & $0.09-1.41$ & 0.14 \\
\hline \multicolumn{4}{|c|}{ Early breastfeeding initiation } \\
\hline Yes & 1 (Ref) & & \\
\hline No & 0.71 & $0.19-2.59$ & 0.60 \\
\hline \multicolumn{4}{|c|}{ Time of colostrum discharge } \\
\hline$\leq 6$ hours & 1 (Ref) & & \\
\hline$>6$ hours & 2.57 & $1.04-6.37$ & 0.04 \\
\hline \multicolumn{4}{|c|}{ Breastfeeding frequency in 24 hours } \\
\hline$\geq 8$ times & 1 (Ref) & & \\
\hline$<8$ times & 2.2 & $0.47-10.23$ & 0.31 \\
\hline
\end{tabular}

terms of maternal education, neonatal age and sex, parity and pre-eclampsia ( $\mathrm{p}>0.05)$.

In Table 2, it is shown that the crude OR of cesarean section was significantly lower than spontaneous labor (crude OR=0.35; 95\%CI: 0.14-0.85) and there was no association between other risk factors with neonatal jaundice; however, multivariate analysis discovered that the only variable associated with neonatal physiological jaundice was the time of colostrum $>6$ hours with adjusted $\mathrm{OR}=2.57$ (95\%CI: 1.04-6.37) (Table 3).

\section{DISCUSSION}

In this study, the only variable that increases the risk of neonatal jaundice is physiological time of colostrum discharge $>6$ hours. The result of this study is similar with a cohort study conducted in Purwokerto which found a difference in the occurrence of neonatal physiological jaundice, wherein neonates with colostrum $>6$ hours were 13.5 times more likely to experience physiological jaundice compared to neonates given colostrum $\leq 6$ hours. ${ }^{18}$ The possible explanation is when the baby's intestine is stimulated with early colostrum discharge, this can accelerate the process of removing meconium and reduce the likelihood of the occurrence of jaundice. ${ }^{23}$ Bilirubin released through meconium can lower serum bilirubin levels. Colostrum is very necessary for baby's growth, as a natural laxative, ripening the intestinal wall and preventing jaundice in newborns. ${ }^{24}$ 
In our study it was found that several variables were not found to be risk factors for neonatal physiological jaundice, namely: the mode of delivery, frequency of breastfeeding within 24 hours and initiation of early breastfeeding. Cesarean delivery was not a risk factor for neonatal physiological jaundice (AOR=0.36; 95\%CI: 0.09-1.41; $\mathrm{p}=0.14$ ). This was also documented in some studies that found no significant association between the method of delivery and neonatal physiological jaundice. ${ }^{9,12,13}$ A different result was found in other studies which found a correlation between the mode of delivery and physiological jaundice in neonates. ${ }^{10,11,17}$

Frequency of breastfeeding less than 8 times in 24 hours was neither a physiological jaundice risk factor in neonates (AOR=2.20; 95\%CI: 0.47-10.23; $\mathrm{p}=0.31)$. In our study, the proportion $(48.51 \%)$ of breastfeeding frequency of $\geq 8$ times in 24 hours in cases was not much different from the proportion $(51.49 \%)$ of breastfeeding frequency $\geq 8$ times in 24 hours in the control group. Other studies discovered a different situation wherein the average serum bilirubin level in newborns with breastfeeding frequency less than or equal to 7 times per day was found to be higher than that of newborns with breastfeeding frequency of more than 7 times per day. ${ }^{25}$ The difference in these results is likely due to the different study designs and the cut off points of the breastfeeding frequency. ${ }^{25}$ In our study, we used a case control study design while the study conducted at the Ghaem Hospital used a cross sectional study design. ${ }^{25}$ The frequency of breastfeeding cut off points was 8 times in our study while it was 7 times in the study conducted at Ghaem Hospital. ${ }^{25}$

In our study, early breastfeeding initiation was not a risk factor for physiological jaundice (AOR $=0.71 ; 95 \% \mathrm{CI}$ : 0.19-2.59; $\mathrm{p}=0.60$ ). A prospective study conducted in Turkey also showed that there is no association between early breastfeeding initiation and bilirubin levels in neonates. ${ }^{13}$ The insignificant association between early breastfeeding initiation and neonatal jaundice may be related to the release of colostrum and bilirubin through meconium which prevents physiological jaundice in neonates. The other possible factors are the volume of intake given, the frequency of breastfeeding and the correct breastfeeding technique that may play a role in the occurrence of physiological neonatal jaundice. ${ }^{13}$ Another explanation is that breastfeeding is influenced by the regulation of the hormones of estrogen, progesterone, prolactin and oxytocin therefore there is a very complex interaction. ${ }^{26}$

The limitation in this study is that all patients who gave birth with cesarean section did not initiate early breastfeeding. Another possible bias is the validity of information provided by the mother regarding the early breastfeeding initiation practice. Additionally, there are some factors which were not investigated such as the nutrition status of mothers, breast massage practice, mothers' psychological condition and possible infections.

In addition, this study was only carried out in one maternity room at Sanglah General Hospital, so caution is needed before generalizations are made to other populations.

\section{CONCLUSION}

The risk factor for neonatal physiological jaundice is the time of colostrum discharge $>6$ hours. Cesarean section, late breastfeeding initiation and breastfeeding frequency $<8$ times were not risk factors for neonatal jaundice. Various efforts are needed to improve the acceleration of the colostrum release and early initiation of breastfeeding.

\section{ACKNOWLEDGEMENT}

We would like to thank the Managing Director of the Sanglah General Hospital, the head and staff of Cempaka 2 Maternity Room and all respondents who have participated in this study.

\section{REFERENCES}

1. Ho NK. Neonatal jaundice in Asia. Bailliere's clinical haematology. 1992. 5(1), 131-142.

2. Brits H, Adendorff J, Huisamen D, Beukes D, Botha K, Herbst $\mathrm{H}$, et al. The prevalence of neonatal jaundice and risk factors in healthy term neonates at National District Hospital in Bloemfontein. African Journal of Primary Health Care and Family Medicine. 2018; 10(1): 1-6.

3. Rubaltelli FF. Unconjugated and conjugated bilirubin pigments during perinatal development. Neonatology. 1993; 64(2-3): 104-109.

4. Nadir SJ, Saleem N, Amin F, Mahmood KT. Rational use of phototherapy in the treatment of physiologic jaundice neonatorum. Journal of Pharmaceutical Sciences and Research. 2011; 3(1): 973-979.

5. Depra M, Recca R, Marongiu GF. Problems of neonatal jaundice. Minerva Pediatrica, 1974; 26(5): 260-263.

6. Urs A, Shivashankar S, Simon C. Neonatal jaundice. Education and Inspiration for General Practice. 2010; 3(12): 708-713.

7. Aride C, Barron J, Benjamin Y. Neonatal jaundice: NICE Clinical Guideline. National Collaborating Centre for Women's and Children's Health. 2010. Available at: https://www.nice.org.uk/guidance/cg98/evidence/ full-guideline-245411821

8. Prasetyono DS. Buku pintar ASI eksklusif [Book of exclusive breastfeeding]. 2009. DIVA. Yogyakarta.

9. Agarwal V, Singh V, Goel SP, Gupta B. Maternal and neonatal factors affecting physiological jaundice in Western UP. Indian Journal of Physiology and Pharmacology. 2007; 51(2): 203-206.

10. Garosi E, Mohammadi F, Ranjkesh F. The relationship between neonatal jaundice and maternal and neonatal factors: a cross sectional study. Iranian Journal of Neonatology. 2012; 7(1):37-40.

11. Osborn L, Reiff MI, Bolus R. Jaundice in the full-term neonate: Prospective cohort study. Pediatrics. 1984; 73(4): 520-525. 
12. Sareharto TP, Wijayahadi N. Kadar Vitamin E rendah sebagai faktor risiko peningkatan bilirubin serum pada neonatus: nested case control [Low Vitamin $\mathrm{E}$ as a risk factor of the bilirubin increase in neonates]. Sari Pediatri. 2010; 5(11):355-362.

13. Bilgin BS, Koroglu OA, Yalaz M, Karaman S, Kultursay N. Factors affecting bilirubin levels during first 48 hours of life in healthy infants: a prospective study. Biomed Research International. 2013; 1-6.

14. Kusika NPS, Lasmini PS. Pengaruh inisiasi menyusu dini terhadap waktu pengeluaran dan perubahan warna mekonium serta kejadian ikterik fisiologis [The influence of early breastfeeding initiation towards the time and color changes of meconium, and the incidence of physiological jaundice]. Jurnal Ilmu Kedokteran. 2015; 9(2): 87-94.

15. Pohlman MN, Nursanti I, Anto YV. Hubungan inisiasi menyusu dini dengan jaundice neonatorum di RSUD Wates Yogyakarta [The association of early breastfeeding intiation and neonatal jaundice at Wates Hospital Yogyakarta]. 2015; 4(2): 96-103.

16. Aulia, Ismail D, Sulistyaningsih. Pengaruh inisiasi menyusu dini terhadap terjadinya jaundice neonatorum di RS PKU Muhammadiyah Bantul [The influence of early breastfeeding initiation towards neonatal jaundice at PKU Muhammadiyah Hospital Bantul]. 2016; 2(1): 31-38.

17. Apriyulan EM. 2017. Hubungan frekuensi pemberian ASI dengan derajat jaundice neonatorum fisologis di PKU Muhammadiyah 1 Yogyakarta (Disertasi) [The association of breastfeeding frequency and the grades of physiological neonatal jaundice at PKU Muhammadiyah 1 Yogyakarta (Dissertation)]. Yogyakarta: Universitas Aisyiyah

18. Tazami RM, Syah S, Jambi U. Gambaran faktor risiko jaundice neonatorum pada neonatus di Ruang Perinatologi RSUD Raden Mattaher Jambi: cross sectional [Risk factors of neonatal jaundice among neonates in Perinatology Ward, Raden Mattaher Hospital Jambi: cross sectional]. Jambi Medical Journal. 2013; 1(1):1-7.

19. Maisels MJ, DeRidder JM, Kring EA, Balasubramaniam M. Routine transcutaneous bilirubin measurements combined with clinical risk factors improve the prediction of subsequent hyperbilirubinemia. Journal of Perinatology. 2009; 29(9): 612-617.
20. Suryandari AE, Agustina EE. Perbedaan waktu pemberian kolostrum terhadap kejadian jaundice fisiologis pada bayi baru lahir di RSU Prof. Dr. Margono Soekarjo: Kohort [Time difference of colostrum initiation and physiological jaundice among newborns in Prof. Dr. Margono Soekarjo Hospital: Cohort]. 2013. Involusi Jurnal Ilmu Kebidanan. 2: $1-12$

21. Rohani S, Wahyuni RR. Faktor-faktor yang berhubungan dengan kejadian ikterus pada neonatus [Factors associated with neonatal jaundice]. Jurnal Aisyah: Jurnal Ilmu Kesehatan. 2017; 2(1): 75-80.

22. Kramer LI. Advancement of dermal icterus in the jaundiced newborn. American Journal of Diseases of Children. 1969; 118(3): 454-458.

23. Bobak IM, Lowdermilk DL, Jensen MD. Buku Ajar Keperawatan Maternitas [Teaching book on maternity care]. 2005. Jakarta: EGC.

24. Haryono R, Setianingsih S. Manfaat ASI eksklusif untuk buah hati Anda [The benefits of exclusive breastfeeding for your children]. 2014. Yogyakarta: Gosyen.

25. Hassan B, Zakerihamidi M. The correlation between frequency and duration of breastfeeding and the severity of neonatal hyperbilirubinemia. Journal of Maternal-Fetal and Neonatal Medicine. 2018; 31(4): 457-463.

26. Indonesian Pediatric Society. Manajemen laktasi [Lactation management]. 2013. Available at: http://www. idai.or.id/artikel/ klinik/asi/manajemen-laktasi diakses tgl 17 Juli 2018

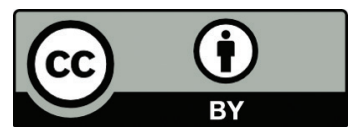

This work is licensed under a Creative Commons Attribution 